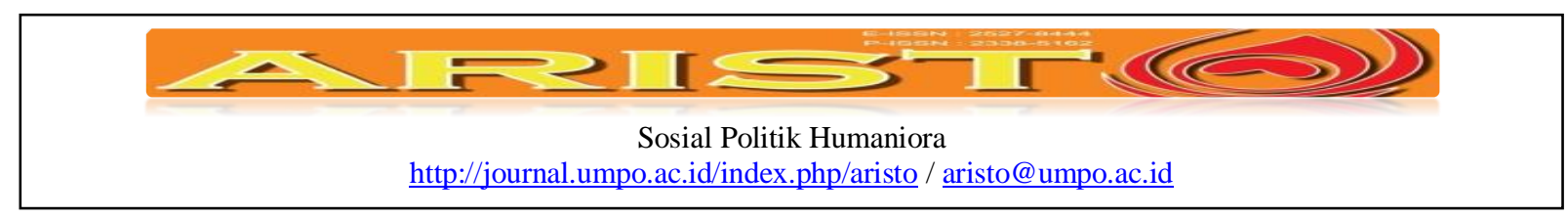

\title{
Inquisitorial: Menelusuri Titik Terminal Keberangkatan Ilmu Pemerintahan Di Indonesia
}

\author{
T. Fahrul Gafar, Zamhasari Jamil \\ Universitas Abdurrab, Pekanbaru - Riau \\ gaffar@univrab.ac.id / zamhasari@univrab.ac.id
}

\begin{abstract}
This research is a scientific effort to trace the historical footsteps of the birth, growth, and development of Government Science in Indonesia. The disclosure of the early phenomenon of science would certainly be the gateway in giving a pure understanding of that science. so that, the result of its inquiry can serve as one of the main sources/ references that provide complete and comprehensive information for further study of Government Science. This study used a qualitative approach with descriptive type and with the library research form. In this study, the researcher observed the object of research through literature materials so that the theories underlying the problems in the field under study can be clearly revealed. With the selection of approaches, types, and forms of research, will certainly be able to reveal in depth how the historical roots of Government Science and able to emphasize the locus / position of Government Science among other state sciences.
\end{abstract}

Keywords: Inquisitorial, Government Science, Indonesia

\begin{abstract}
Abstrak
Penelitian ini adalah sebuah usaha ilmiah untuk melacak serta mengikuti langkah-langkah sejarah kelahiran, pertumbuhan, dan pengembangan ilmu pemerintahan di Indonesia. Pengungkapan fenomena awal ilmu dalam memberikan pemahaman yang baik dari ilmu pengetahuan. Sehingga, hasil dari penelitian dapat berfungsi sebagai salah satu sumber utama / referensi yang menyediakan secara lengkap dan komprehensif informasi untuk studi lebih lanjut ilmu pemerintahan. Studi ini menggunakan pendekatan kualitatif dengan jenis dan dengan perpustakaan deskriptif penelitian membentuk. Dalam studi ini, kata para peneliti itu diamati objek penelitian melalui bahan sehingga teori sastra yang mendasari masalah di lapangan dalam kajian dapat jelas mengungkapkan. Dengan pemilihan dari pendekatan, jenis, penelitian dan bentuk, akan dapat kedalaman bagaimana untuk mengungkapkan dalam akar sejarah ilmu pemerintahan dan mampu menekankan lokus / posisi ilmu pemerintahan antara lain ilmu admisitrasi Negara.
\end{abstract}

Kata Kunci: Inkuisisi, Ilmu Pemerintahan, Indonesia

\begin{tabular}{|ll}
\hline Submite & $:$ 10 September 2017 \\
Review & $:$ 25 November 2017 \\
Accepted & $:$ 01 Januari 2018 \\
Surel Corespondensi & $:$ arifzainudin@ gmail.com
\end{tabular}

T. Fahrul Gafar, Zamhasari Jamil, Inquisitorial: Menelusuri Titik Terminal Keberangkatan Ilmu Pemerintahan Di Indonesia /10/ 


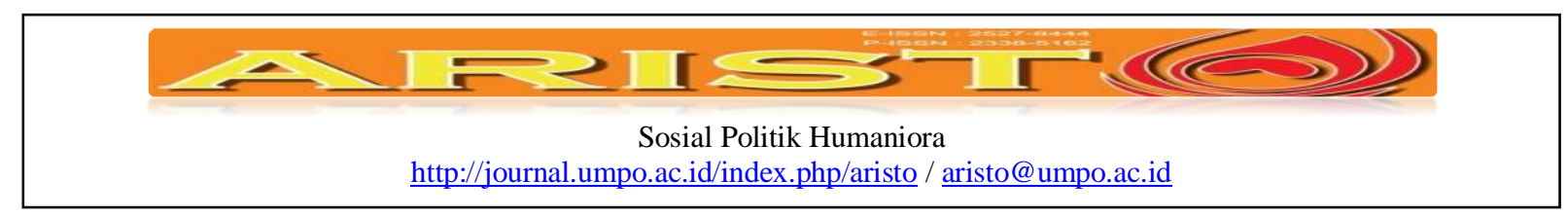

\section{Pendahuluan}

Sebuah ilmu berangkat dari pengetahuan-pengetahuan yang bergerak bebas tanpa simpul dialam fikir manusia. Kemudian timbullah keinginan manusia yang menyimpan hasrat keingintahuan (curiosity) yang begitu besar tersebut kedalam sebuah tertib susunan pengetahuan secara sistematis, metodis, dan koheren. Mengapa demikian? Wasistiono (2003) menjelaskan bahwa ilmu dapat diibaratkan seperti organisme hidup, yang lahir-tumbuh-berkembang dan mungkin juga pada akhirnya akan mati. Panjang atau pendeknya lingkaran hidup sebuah ilmu akan sangat tergantung pada kemampuannya dalam menjalankan fungsi-fungsi keilmuannya.

Hal yang demikian juga terjadi pada Ilmu Pemerintahan, walau tak satupun yang menyangkal bahwa pemerintah dan pemerintahan telah dipelajari sejak kira-kira tahun 400 Sebelum Masehi (S.M). Ahli-ahli fikir seperti Plato (429-347 S.M) telah menulis tentang pemerintahan dalam bukunya yang berjudul "Politeia”. Karya lain dari Plato yang judulnya juga diturunkan dari kata "polis" ialah "politikos" yang isinya membahas berbagai masalah yang berkaitan dengan pemerintahan dan kepemimpinan polis (kota). Selain Plato ada juga muridnya yang bernaman Aristoteles (384-322 S.M) yang menelurkan buah fikirnya kedalam buku yang berjudul "Politica". Judul ini juga mengandung arti "polis" dan membicarakan tentang ke-polisan (Surianingrat, 1980). Istilah "polis" terus merambah merasuki zaman modern dengan bentuk yang agak berubah, misalnya politic (Inggris), politicus/policia (Latin), polizei (Jerman), politie (Belanda), dan polisi (Indonesia). Akan tetapi, ilmu tentang pemerintahan polis ini, oleh banyak sarjana dinamakan sebagai ilmu kenegaraan atau ilmu tentang negara, karena "polis" diterjemahkan sebagai "negara".

Di Indonesia, pemahaman tentang pemerintahan baik sebagai sebuah kajian ataupun sebuah ilmu juga memiliki beragam corak dan sudut pandang (mazhab). Dari beberapa hasil penelitian dan proposisi pemikiran dalam berbagai publikasi ilmiah yang dapat penulis sajikan dalam tulisan ini diantaranya adalah Pratikno (2003),yang berusaha memberikan klarifikasi awal tentang apa itu pemerintahan, (governmental "science") "sains" pemerintah, dan studi pemerintah (governmental studies). Lebih lanjut ia membuka penilaian dengan menguraikan istilah pemerintahan dan politik melalui pengamatan fungsinya dari berbagai literatur terpilih. Pembahasan topik ini akan didukung oleh review mengenai alasan dibalik jurusan Ilmu Politik (jurusan ilmu politik) dan jurusan ilmu Pemerintahan (jurusan ilmu pengetahuan pemerintah), 


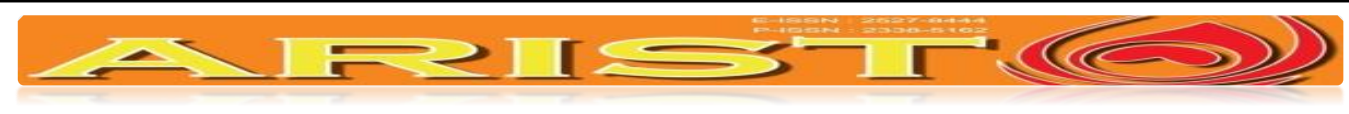

Sosial Politik Humaniora

$\underline{\text { http://journal.umpo.ac.id/index.php/aristo / aristo@umpo.ac.id }}$

dan pembahasannya diakhiri dengan sebuah usulan untuk memprakarsai studi pemerintah, sebagai alternatif dari "ilmu" pemerintahan. Selain itu, Lay dan Masudi (2005), berupaya menjelaskan ruang lingkup kajian politik dan pemerintahan yang berkisar pada dinamika institusi pemerintah dan lembaga pemerintah formal yang berada pada aspek negara, masyarakat dan pasar termasuk hubungan dari aspek-aspek ini, sehingga wacanapemerintahan menjadi dominan dalam ilmu politik khususnyadalam studi pemerintahan.Selanjutnya Ylst (2015) mempertanyakan apakah IlmuPemerintahan "eksis" atau tidak? Pertanyaan tersebut dapat terjawab secara "sangatmemuaskan" melalui pencaharian terhadap fundamental Ilmu pemerintahan dari jalan "Philosophy of Science", dimana syarat pokok dari keberadaan suatuilmu pengetahuan menjadi titik awal dari pemaparannya melalui tinjauan terhadap ilmu pengetahuan itu sendiri (ontologis), bagaimanakah ruanglingkup dan objeknya (epistemologis), dan apakah yang menjadi tujuan utama dariilmu pengetahuan tersebut (axiological)?. Terakhir, tidak jauh berbeda dengan yang sebelumnya, Karniawati (2015) menulis perbedaan pandangan dari beberapa ahli tentang apa itu hakikat, objek, dan kajiandari Ilmu Pemerintahan, dimana pada umumnya, Ilmu Pemerintahan dikenal sebagai ilmuyang mempelajari tentang hubungan pemerintah dengan yang diperintah dengan melihat Ilmu Pemerintahanmelalui landasan ontologi, landasan epistemologi, dan landasan aksiologi.

Berdasarkan gejaladan kajian yang pernah dilakukan sebelumnya, sampailah kita pada pertanyaan kritis dan krusial, apakah Ilmu Pemerintahan adalah sebuah ilmu pengetahuan yang berdiri sendiri (stand-alone science) ataukah hanya merupakan bagian integral dari ilmu-ilmu lain?. Untuk bisa mengatakan dengan tegas ya atau tidak, maka diperlukan sebuah penelitian yang mendalam tentang bagaimana sejarah kebermulaan Ilmu Pemerintahan di Indonesia dan bagaimana pula lokus/ kedudukannya diantara ilmu-ilmu kenegaraan lainnya. Dari jalan tersebut diharapakan akan melahirkan sebuah pemahaman yang luhur dan murni yang merupakan maksud dan tujuan dari penelitian ini.

\section{Metode dan Kepustakaan}

Penelitian ini menggunakan pendekatan kualitatif dengan jenis deskriptif yang akan lebih mengarahkan kegiatan penelitian pada penggambaran secara spesifik tentang fenomena tertentu dengan bentuk penelitian kepustakaan (library research), dimana peneliti mengamati obyek 


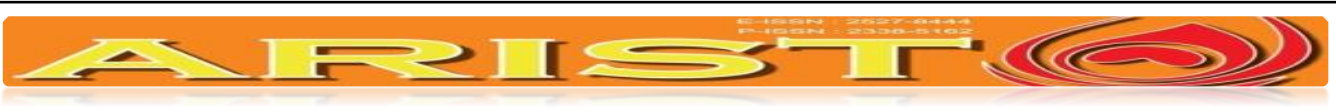

Sosial Politik Humaniora

http://journal.umpo.ac.id/index.php/aristo / aristo@umpo.ac.id

penelitian melalui bahan-bahan kepustakaan, sehingga teori-teori yang mendasari masalah pada bidang yang diteliti dapat diungkap dengan jelas. Dengan pemilihan pendekatan, jenis dan bentuk penilitian ini, tentunya akan mampu mengungkap secara mendalam bagaimana akar sejarah Ilmu Pemerintahandi Indonesia.

\section{Pengertian Ilmu, Pengetahuan, dan Ilmu Pengetahuan}

Pengertian ilmu dirujuk dari kata 'ilm (Arab), scio/scire (Latin/Spanyol) science (Inggris), wetenschap (Belanda), dan wissenschaf (Jerman) (Syafiie, 2000). Namun orang-orang yang pernah mempelajari bahasa Arab mengalami sedikit kebingungan tatkala menemui kata "ilmu". Dalam bahasa Arab kata al- 'ilm berarti pengetahuan (knowledge), sedangkan kata "ilmu" dalam bahasa Indonesia biasanya terjemahan dari kata science. Ilmu dalam arti science itu hanya sebagian dari al-ilm dalam bahasa Arab. Oleh karena itu, dalam mata kuliah Filsafat Pengetahuan (Philosophy of Knowledge) yang didiskusikan bukan hanya pengetahuan sains (science) akan tetapi juga mendiskusikan segala sesuatu yang tergolong pengetahuan termasuk pengetahuan yang “aneh-aneh" seperti pelet, santet, kebal, kanuragan, dan lain-lain. Karena itu kata science seharusnya diterjemahkan "sains" saja agar orang yang mengerti bahasa Arab tidak sulit membedakan kala al-'ilm yang berarti knowledge (Tafsir, 2004).

Ilmu selalu diartikan sebagai pengetahuan, namun tidak semua pengetahuan dapat dinamakan sebagai ilmu, karena ilmu merupakam pengetahuan yang diperoleh dengan cara-cara tertentu berdasarkan kesepakatan para ilmuwan. Harre (1995) mengatakan bahwa ilmu adalah " $a$ collection of well-attested theories which explain the patterns regularities and irregularities among carefully studied phenomena",pernyataan tersebut mengandung makna bahwa ilmu merupakan kumpulan teori-teori yang sudah diuji coba yang menjelaskan tentang pola-pola yang teratur atau pun tidak teratur diantara fenomena yang dipelajari secara hati-hati. Oleh karenanya, dalam kajian filsafat, ilmu dan pengetahuan dibedakan, pengetahuan bukan berarti ilmu, tetapi ilmu merupakan akumulasi dari pengetahuan sebagaimana berbedanya antara science dan knowledge dalam bahasa Inggris. Lalu bagaimana dengan pengetahuan? secara sederhana yang disebut dengan pengetahuan adalah segala sesuatu yang diketahui. Hal tersebut selaras dengan perkataan Surianingrat (1980) yang menjelaskan bahwa pengetahuan berarti hal mengetahui sesuatu atau segala apa yang diketahui. Jadi, dalam kata pengetahuan tersimpul dua unsur: 


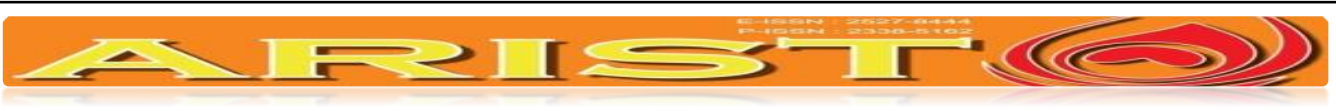

Sosial Politik Humaniora

$\underline{\text { http://journal.umpo.ac.id/index.php/aristo / aristo@umpo.ac.id }}$

pertama; yang mengetahui, dan kedua; yang diketahui. Sedangkan pengertianyang bulat dan utuh tentang ilmu pengetahuanditandaskan oleh Gie (1991), bahwa ilmu pengetahuan adalah rangkaian aktifitas manusia yang rasional dan kognitif dengan berbagai metode berupa aneka prosedur dan tata langkah sehingga menghasilkan kumpulan pengetahuan yang sistematis mengenai gejala-gejala kealaman, kemasyarakatan atau individu untuk tujuan mencapai kebenaran, memperoleh pemahaman, memberikan penjelasan ataupun melakukan penerapan.

\section{Makna Pemerintah dan Pemerintahan: Pendekatan Linguistic (Kebahasaan)}

Secara etimologis kata Pemerintah dan Pemerintahan ditarik dari kata "titah". Dari sudut leksikal berarti amanat, amar ( $a l$ - 'amr), sabda, dan firman yang semuanya bermakna "perintah" (Endarmoko, 2006). Kata "titah" dapat dikatakan sejajar dengan kata gubernaculum/gubernare (Latin/Spanyol), kybern (Greek/Yunani), dan govern (Inggris). Sehingga dikenal menjadi Governing/ steering dalam bahasa Inggris dan gubernare dalam bahasa latin, sedangkan dalam bahasa Gerika (Greek/Yunani) adalah kybernan. Gubernaculum/ gubernare kemudian berubah menjadi gubernantia. Sedangkan dalam bahasa Belanda, berasal dari kata besturen (mengemudi = Inggris: steering) ditambah kunde (kepandaian = Inggris: craft, skill) (Ndraha, 2003). Peleburan dua kata itulah yang membentuk katabestuurkunde yang kemudian berkembang menjadi bestuurwetenschap, dan bestuurwetenschappen (jamak); weten artinya "mengetahui", sedang schap artinya "ilmu", maka wetenschap berarti“ilmu pengetahuan". Secara utuh, definisi dan makna kata governmentjuga termaktub dalam Black's Law Dictionary yang berbunyi: “From the Latin gubernaculum. Signifies the instrument, the helm, whereby the ship to which the state was compared, was guided on its course by the "gubernator" or helmsman, and in that view, the government is but an agency of the state, distinguished as it must be in accurate thought from its scheme and machinery of government” (Black’s Law Dictionary, 1979).

\section{Makna Pemerintah dan Pemerintahan: Pendekatan Scientific (Keilmuan)}

Makna pemerintah dan pemerintahan terus berkembang dengan lahirnya karya-karya ilmiah yang berusaha merumuskkan makna pemerintahan (defining government and governance) baik dari luar maupun dalam negeri hingga beberapa dekade belakangan, diantaranya : 


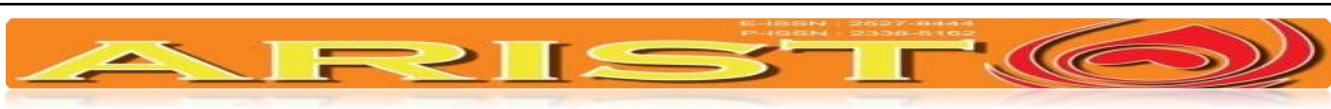

Sosial Politik Humaniora

http://journal.umpo.ac.id/index.php/aristo / aristo@umpo.ac.id

1. Herman Finer (1949) dalam bukunya Theory and Practice of Modern Government mengatakan dengan jargon yang ramah ditelinga kita yaitu "government is politics plus administration"

2. C. F. Strong (1960) dalam buku Modern Political Constitutional mengatakan bahwa pemerintahan adalah organisasi dalam mana diletakkan hak untuk melaksanakan kekuasaan berdaulat atau tertinggi.

3. Samuel Edward Finer (1974) dalam bukunya Comparative Government mengatakan bahwa pertama, the activity or the process of governing. Kedua, state of affairs. Ketiga, people charged with the duty of government. Keempat, the manner, method or system by which a particular society is governed.

4. S. Pamudji (1983) dalam bukunya yang berjudul Kepemimpinan Pemerintahan di Indonesia yang mengatakan bahwa Pemerintah adalah kekuasaan memerintah suatu negara (daerah negara) atau badan yang tertinggi yang memerintah sesuatu negara (seperti kabinet merupakan suatu pemerintah).

5. Bayu Surianingrat (1980) Mengenal Ilmu Pemerintahan mengatakan bahwa Pemerintahan adalah orang atau badan atau perangkat yang menyelenggarakan pemerintahan atau yang memerintah.

6. Taliziduhu Ndraha (2003) dalam karya monumentalnya Kybernologi (Ilmu Pemerintahan Baru) yang berkata bahwa pemerintahan adalah gejala sosial, yang artinya terjadi hubungan antar anggota masyarakat, baik individu dengan individu, individu dengan kelompok, maupun antar individu dengan kelompok.

Berdasarkan tinjauan kepustakaan, puncak pemahaman yang hadir dibenak kita adalah, bahwa ilmu pengetahuan yang utuh dan kukuh berasal dari gejala dan fenomena yang tertangkap sebagai titik pangkal dalam kegiatan penelitian dimana pengetahuan yang berhasil ditangkap dari gejala dan fenomena tersebut kemudian diproses dalam sebuah aktifitas penelitian melalui prosedur dan tata langkah tertentu yang pada akhirnya melahirkan produk ilmu pengetahuan yang sistematis, metodis, dan koheren. Ilmu Pemerintahan telah melalui proses dalam life cycle/ siklus hidup ilmu pengetahuan yang sesuai dengan pembabakan dan tahapan dalam prinsipprinsip serta hukum-hukum penemuan ilmiah sebagaimana yang dipersyarat tersebut. Sebagai upaya pembuktian, tulisan ini berusahamenegaskan kambali arti dan eksistensi Ilmu 


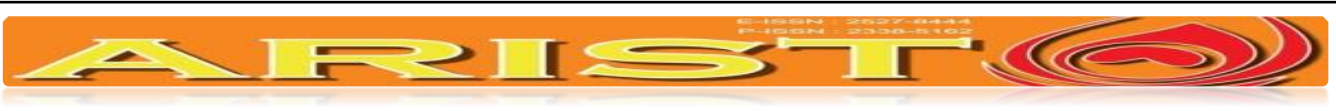

Sosial Politik Humaniora

http://journal.umpo.ac.id/index.php/aristo / aristo@umpo.ac.id

Pemerintahan dengan melacak dan merunutkan jejak kesejarahannya, diperkuat dengan berbagai pendapat dan pandangan dari para pakar atau ilmuwannya perihal lokus atau kedudukan Ilmu Pemerintahan yang tersebar dalam berbagai buku dan literatur terdahulu.

\section{Hasil dan Pembahasan}

\section{Sejarah Kebermulaan Ilmu Pemerintahan di Indonesia}

Perkembangan Ilmu Pemerintahan di Indonesia tidak terlepas dari pelaksanaan pemerintahan penjajahan Hindia Belanda di Indonesia, pada masa inilah berbagai pengetahuan pemerintahan mulai dikenalkan oleh pemerintah Hindia Belanda di Indonesia dalam kerangka penyelenggaraan pemerintahan yang lebih efektif untuk kepentingan Pemerintah Hindia Belanda.Penjajahan yang terjadi terhadap tanah air kita oleh bangsa Belanda dalam waktu yang begitu panjang, menjadikan banyak aspek dari sistem pemerintahan yangberlaku dinegeri Belanda (yang pada umumnya menganut sistem Perancis/Jerman) juga diterapkan di Indonesia, sehingga menyebabkan sistem tersebut memiliki pengaruh yang besar sekali dalam pelaksanaan pemerintahan di Indonesia hingga dewasa ini. Selain itu, pergeseran juga terjadi melalui transmisi budaya ilmu pengetahuan, maka perkembangan llmu Pemerintahan dinegeri Belanda semenjak jaman Kameralisme (sistem/model penerapan pemerintahan di Jerman dan Prancis) hingga lahirnya Bestuurswetenschap dan Bestuurswetenschappen dalam abad ke-20 memberikan pengaruh yang besar terhadap perkembangan pemikiran-pemikiran tentang pemerintahan di Indonesia. Setelah menjadi bangsa yang merdeka, barulah Indonesia menerima pengaruh dari sistem pemerintah Anglo-Amerika, serta menerima pengaruh dari perkembangan Ilmu Public Administration. Salah satu aspek dari sistem pemerintahan perancis/jerman yang diterapkan adalah upaya untuk menciptakan suatu pemerintahan pusat yang kuat, yang dapat mengendalikanotoritas dari pemerintahan-pemerintahan regional dan lokal. Untuk itu diciptakan sebuah asas yang disebut dengan asas dekonsentrasi, yang pelaksanaanya dipercayakan kepada suatu korps pegawai khusus yaitu Binnenlandsch Bestuur scorps, yang kemudian dialihbahasakan kedalam Bahasa Indonesia menjadi "Pangrehpraja" dan semenjak Indonesia merdeka kemudian berubah menjadi "Pamongpraja". Setelah proklamasi kemerdekaan, Korps Pamongpraja ikut serta secara aktif dalam usaha mewujudkan sistem pemerintahan dari Negara Kesatuan Republik Indonesia yang berdasarkan Pancasila. Secara resmi, kesetiaan dari korps ini 


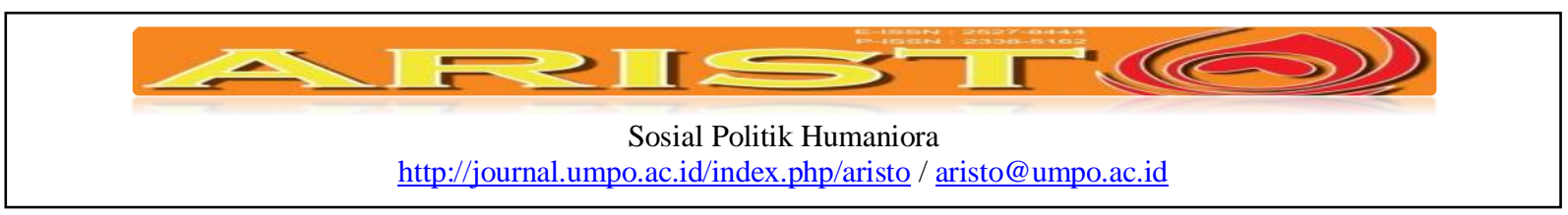

dinyatakan dalam pertemuan mereka di Solo pada permulaan Tahun 1946. Namun dalam perkembangannya berikutnya, yaitu keadaan yang terjadi selama perjuangan rakyat Indonesia melawan Belanda dengan adanya agresi militer Belanda I pada tahun 1947 dan agresi II tahun 1948 dan 1949, membuat Pamongpraja RI terpaksa harus menyingkir atau mengungsi dengan cara terus bergerilya bahu-membahu bersama TNI dan rakyat. Dalam fase ini, banyak Pamongpraja Republik Indonesia yang gugur dimedan pertempuran. Dengan kondisi yang seperti itu akhirnya menyebabkan berbagai masalah. Masalah pertama; banyak jabatan Pamongpraja menjadi kosong, baik pada eselon-eselon yang tinggi maupun pada eselon-eselon yang lebih rendah yaitu adalah jabatan-jabatan pada eselon-eselon yang tinggi (yang diduduki oleh the higher rank officials dan the higher-midle rank officials), yang semula hanya dapat dijabat oleh orang-orang Belanda (dan kemudian oleh orang-orang Jepang). Jabatan-jabatan ini kemudian harus diisi oleh pejabat-pejabat yang diambilkan dari eselon yang lebih rendah yaitu dari the lower middle rank officials, bahkan the lower rank officials, dengan kualifikasi yang tentunya masih kurang mencukupi. Lowongan-lowongan jabatan yang timbul pada eselon yang lebih rendah ini kemudian harus pula diisi oleh pejabat-pejabat yang diambilkan dari eselon yang lebih rendah lagi, demikianlah seterusnya sehingga terjadi semacam promosi yang dipaksakan pada setiap jenjang eselon tanpa memperhatikan kualifikasi. Masalah kedua; adalah kelanjutan dari masalah pertamayang disebabkan oleh banyaknya lowongan-lowongan yang terjadi karena banyak pejabat yang gugur atau mengungsi, sehingga lowongan-lowongan tersebut harus segera diisi dengan tenaga-tenaga yang mempunyai kualifikasi dan pengetahuan yang seadanya demi kelanjutan perjuangan. Sehingga pada hekekatnya pamongparaja itu merupakan tenaga-tenaga darurat yang diangkat dan ditunjuk langsung oleh atasan, meskipun atasan-atasan ini secara formal juga tidak mempunyai kewenangan untuk mengangkatnya. Dengan demikianbanyak tenaga Pamongpraja Republik Indonesia pada waktu itu yang mempunyai kualifikasi darurat.Dalam pada itu pemerintah federal diwilayah-wilayah yang didudukinya juga mengangkat pejabat-pejabat pemerintahan (masih bernama Pangrehpraja), yang banyak diantaranya juga bersifat darurat. Selanjutnya, semenjak berdirinya Negara Republik Indonesia Serikat (RIS), pengangkatan-pengangkatan seperti itu juga masih tetap dilakukan baik oleh pemerintah RIS maupun oleh Negara-Negara Bagian (Djaenuri, 2016).

Tentunya dapat dimengerti jika Negara Kesatuan Republik Indonesia yang menggantikan 


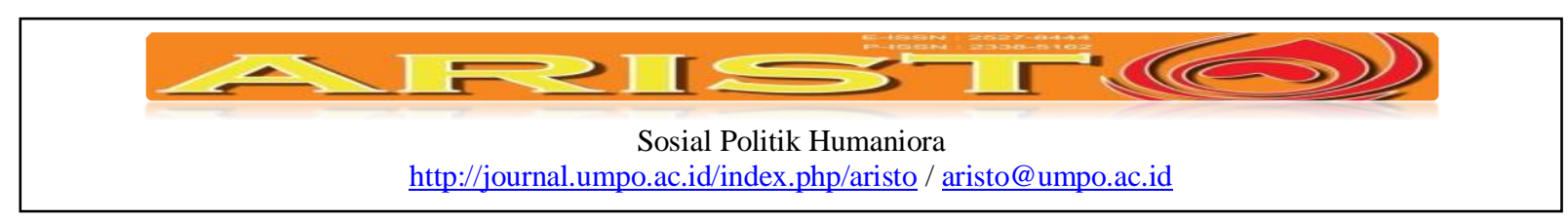

Negara Republik Indonesia Serikat pada awal-awal kemerdekaan menghadapi berbagai problema dalam penyelenggaraannya, seperti misalnya bagaimana menyusun suatu aparatur di lapangan pemerintahan yang tidak hanya mampu dan cakap dalam menyelenggarakan urusan pemerintahan dalam negeri tetapi juga dapat diterima khalayak ramai dan inilah problema pokok dan menonjol yang dihadapi oleh Kementerian Dalam Negeri pada waktu itu. Pada tahap-tahap permulaan, faktor aksebtabilitas memang merupakan syarat utama akan tetapi dalam waktu yang tidak terlalu lama, barulah faktor kapabilitaslah yang diutamakan. Untuk memperoleh tenagatenaga yang kapabel (berkemampuan) dilapangan pemerintahan maka dirintis dan dikembangkalah kembali pendidikan Kepamongprajaan.Pendidikan yang sudah ada sebelum tahun 1949, yaitu SMA Pamongpraja di Solo dan Sekolah Menengah Pamongpraja di Purwekerto yang masing-masing terdiri dari satu angkatan saja, sangat tidak berarti bila untuk mengisi ruang yang disebut sebagai the lower middle rank officials, bahkan the lower rank officials yang kosong dan harus diisi oleh tenaga dengan pendidikan yang sesuai. Oleh karena itu, kekurangan tenaga yang terdidik, khususnya di Kecamatan dan Kewedanan menjadi sangat besar. Hal ini sejalan dengan apa yang dikatakan oleh Soerjosoedarmo (1985), bahwa pada akhir abad 19 Pemerintah Hindia Belanda sudah pernah mendirikan lembaga pendidikan yang tugasnya mendidik calon Pamongpraja pribumi dibeberapa tempat di Indonesia, yang ternyata dalam perkembangannya menarik pemerintah Hindia Belanda untuk mengambangkan pendidikan dimaksud pada jenjang yang lebih tinggi yaitu jenjang OSVIA (Opleiding School Voor Inlands Ambtenaren), sekolah ini menerima tamatan sekolah dasar. Kemudian pada tahun 50an OSVIA ditingkatkan menjadi MOSVIA (Middelbaar School van Inheemse Ambtenaren) yang menerima tamatan MULO (Meer Uitgebreid Lager Onderwijs yang berarti; Pendidikan Dasar Lebih Luas) atau setara dengan Sekolah Menengah Pertama (SMP) sekarang. Tamatan OSVIA yang memiliki kompeten dan berkondite baik dapat melanjutkan studinya ke Bestuurschool selama 2 tahun di Jakarta. Sekolah tersebut membekali pegawai untuk dipersiapkan untuk menjadi pejabat Pamongpraja pada tingkatan Patih. Lebih lanjut sekolah dimaksud ditingkatkan menjadi Bestuur Academie di Jakarta sebagai bagian dari Rechtshogeschool (Sekolah Tinggi Hukum) atas dasar itu corak pendidikannya lebih kebidang hukum yang tujuannya adalah untuk menyiapkan tenaga sebagai pimpinan Pangrehpraja.

Untuk memenuhi kebutuhan akan pegawai-pegawai pamongpraja tingkat menengah (the 


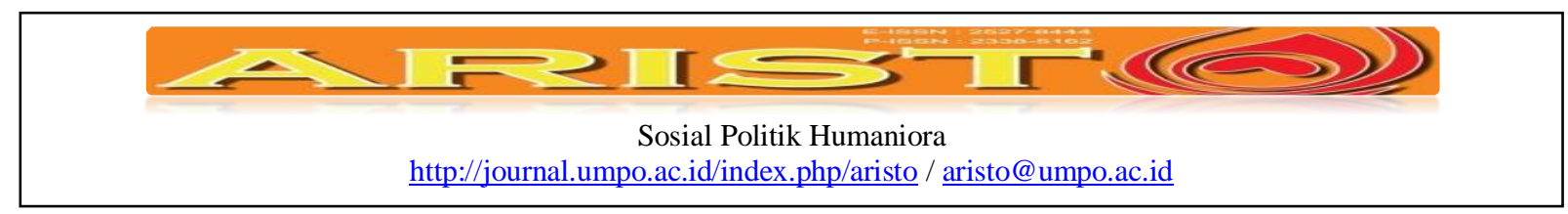

middle rank officials) pada tanggal 15 Maret tahun 1948, Pemerintah Republik Indonesia mendirikan Akademi Ilmu Politik (AIP) di Yogyakarta, yang tujuannya untuk mendidik pegawai atau calon pegawai di departemen-departemen khususnya Departemen Dalam Negeri, Departemen Luar Negeri, dan Departemen Penerangan yang saat itu sangat diperlukan dalam kerangka melancarkan pelaksanaan tugas-tugas Departementasi dan penyelenggaraan pemerintah Negara Kesatuan Republik Indonesia pada umumnya. Dalam perkembangannya dengan Peraturan Pemerintah Nomor 23 tahun 1949 AIP dibubarkan dan diintegrasikan kedalam Universitas Gajah Mada di Yogyakarta karena Akademi Ilmu Politik dimasukan sebagai bagian dari ilmu sosial dan politik, demikian juga dengan ilmu hukumsehingga menjadi Fakultas Hukum, Sosial dan Politik (FHSP) secara resmi pada tanggal 1 September 1952. FHSP kemudiandisusul atau ditambahkan dengan bidang ekonomi dan kemudian dibentuk secara bersama-sama menjadi Fakultas Hukum, Ekonomi, Sosial dan Politik (disingkat FHESP). Bagian Sosial dan Politik fakultas HESP dalam penyelenggaraannya, tenaga pengajarnya banyak didominasi oleh pengajar yang berlatar belakang hukum dalam berbagai mata kuliahnya (Soerjosoedarmo, 1985). Kemudian dengan keluarnya Surat Keputusan Menteri Pendidikan Pengajaran dan Kebudayaan Nomor 5379/Kab. Tanggal 15 September 1955, bagian Sosial dan Politik dipisahkan dari fakultas HESP menjadi fakultas tersendiri yaitu FakultasSosial dan Politik (FSP). Pada tahun 1957, FSP disusun menjadi 5 (lima) jurusan, antara lain; Jurusan Ilmu Usaha Negara (kemudian menjadi Ilmu Administrasi Negara); Jurusan Ilmu Sosiologi; Jurusan Hubungan Internsional; Jurusan Publisistik; Jurusan Pembangunan Sosial dan Kesejahteraan (Sosiatri), namun Jurusan (Ilmu) Pemerintahan justru ditiadakan. Hal ini kemudian memberikan kesan bahwa seakan-akan Ilmu Administrasi Negara sangat identik dengan Ilmu Pemerintahan atau dengan kata lain studi mengenai ilmu pemerintahan menjadi terabaikan. Berdasarkan hal tersebut Soerjosoedarmo (1985) menyimpulkan bahwa :

1. Semula pemerintahan Hindia Belanda mendirikan pendidikan-pendidikan dari berbagai tingkat untuk menyiapkan pegawai-pegawai pemerintahan. Mata kuliah yang diberikan sangat diwarnai oleh hukum ditambah dengan pengetahuan praktik. Akan tetapi mata kuliah Ilmu Pemerintahan sendiri belum dikenal pada waktu itu.

2. Setelah Indonesia merdeka dan mendirikan AIP, jurusan Ilmu Pemerintahankemudian dilanjutkan kembali setelah diintergrasikan dengan Universitas Gajah Mada. Patut untuk 


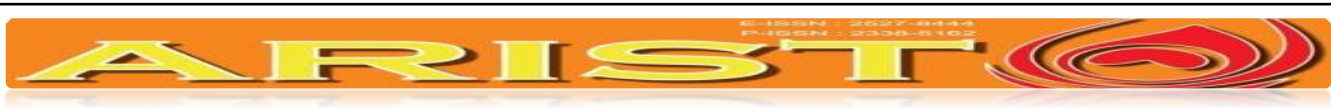

Sosial Politik Humaniora

http://journal.umpo.ac.id/index.php/aristo / aristo@umpo.ac.id

dicatat bahwasanya : (a) Ilmu Pemerintahan mulai diberikan; (b) Mata kuliah tersebut merupakan kurikulum jurusan pemerintahan, terutama mata kuliah dari ilmu hukum; (c) Setelah datang bantuan dari International Cooperation Administration/ICA-AID dari Amerika Serikat beserta para ahli dan pakar-pakar Administrasi Publiknya, mata kuliah Administrasi Publik (Publik Administration) mulai mewarnai jurusan pemerintahan sehingga dipandang perlu diadakan jurusan ilmu Administrasi Negara, disamping menghidupkan kembali jurusan Ilmu Pemerintahan yang pada saat itu masih bernama jurusan Ilmu Usaha Negara; (d) Setelah dikirim beberapa tenaga pengajar ke Inggris dan Amerika Serikat untuk program doktor dan master, maka pengaruh Ilmu Politik pada kurikulum jurusan Ilmu Pemerintahan mulai meningkat.

Kemudian, Sekretaris Jenderal Kementerian Dalam Negeri pada waktu itu merundingkan dengan pimpinan Universitas Gajah Mada dan pimpinan Fakultas Sosial Politik Universitas Gajah Mada (FSP-UGM), yang intinya mempelajari kemungkinan apakah Fakultas Sosial Politik yang bersifat umumitu dapat menyusun suatu kurikulum khusus untuk memenuhi kebutuhan Kemeterian Dalam Negeri yaitu menghasilkan Sarjana Muda "plus" dan Sarjana "plus" dibidang pemerintahan (dalam arti Ilmu) dan Kepamongprajaan (dalam arti seni atau Art). Istilah "plus" berarti bahwa lulusan-lulusan itu disamping memperoleh bekal ilmu pengetahuan yang cukup mendalam juga menguasai keterampilan-keterampilan teknis sehingga mereka juga merupakan orang-orang yang sewaktu-waktu siap untuk melaksanakan tugas-tugas di Kementerian Dalam Negeri dan instansi-intansi atau kantor-kantor di daerah-daerah. Hasil akhir dari pembahasan itu adalah bahwa pendapat dari pihak Universitas Gajah Mada dalam menanggapi maksud dari Kementerian Dalam Negeri itu hanya dapat dipenuhi dengan sebaik-baiknya apabila kurikulumnya secara akademis beorientasi kepada perkembangan ilmu pengetahuan didunia kampus atau universitas pada umumnya, sedangkan yang bersifat praktis dan berorientasi kepada pelaksanaan serta perkembangan tugas-tugasdi Kementerian Dalam Negeri,diperlukan sebuah Lembaga Pendidikan khusus dan tersendiri. Sebagai pelaksana, maka Sekretaris Jenderal Kementerian Negeri bersama orang-orang lain yang dipandang berpengalamandalam bidang kepamongprajaan menyusun kurikulum pada Lembaga Pendidikan khusus dan tersendiri yang bernama Akademi Pemerintahan Dalam Negeri (APDN). Mengenai segi keilmiahan, kurikulum APDN tetap berorientasi kepada Fakultas Sosial Politik Universitas Gajah Mada, setelah 


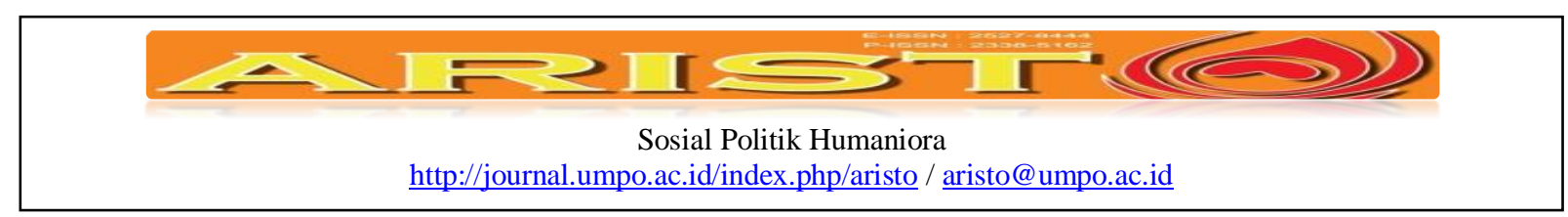

kurikulum tersebut matang, APDN kemudian diresmikan pembukaannya pada tahun 1956 oleh Presiden Pertama Republik Indonesia Ir. Soekarno di Malang Provinsi Jawa Timur (Djaenuri, 2016).

APDN mengawali sistem pendidikan secara terpimpin pada tingkat Unversitas di Indonesia dan yang pertama kali pula menerapkan sistem semester. Dibandingkan dengan kurikulum dari Fakultas Sosial Politik Universitas Gajah Mada, maka kurikulum APDN kelihatan jauh lebih padat mengingat sisipan-sisipan dari mata kuliah praktis seperti diuraikan diatas. Namun kurikulum dengan sajian matakuliah yang padat itu dapat diselenggarakan dengan baik berkat pemanfaatan waktu dalam rangka studi terpimpin.Kuliah-kuliah di APDN berlangsung selama 6 semester (3 tahun), dimana lulusannya diberi gelar Bachelar of Art (BA). Isinya adalah sarjana muda "plus" seperti yang dicita-citakan, merupakan kualifikasi yang dipandang mencukupi untuk jabatan-jabatan kepamongprajaan yang termasuk the lower middle rank positions. Apabila mereka ditugaskan untuk memimpin wilayah maka mereka dipandang mampu untuk menjadi administrator pemerintahan ditingkat kecamatan dengan kata lain mampu untuk menjabat sebagai camat. Untuk menduduki jabatan-jabatan yang diklasifikasikan sebagai the highermiddle rank positions, apalagi untuk dapat menduduki jabatan yang diklasifikasikan sebagai the higher rank position, maka tamatan APDN itu harus dapat menuntaskan wawasan ilmiahnya tanpa mengabaikan ciri tentang penguasaan bidang-bidang pekerjaan yang lebih bersifat teknis yang memang dimaksudkan sejak semula. Setelah didirikannya APDN kemudian didirikan pula studi lanjutannya, semacam tingkat Doktorandus (Drs) yang perkuliahannya memakan waktu sekitar dua tahun. Lembaga sambungan/ lanjutata dari APDN ini mulanya direncanakan akan berdiri pada tahun 1959. Rencana ini agak mengalami hambatan dalam realisasinya disebabkan kondisi politik yang belum stabil. Namun setelah lahirnya Pemerintah Orde Baru rencana tersebut dapat diwujudkan dengan lahirnya Institut Ilmu Pemerintahan (IIP) pada tanggal 25 Mei 1967 yang pembentukannya dilandaskan pada Keputusan Presiden RI No. 119 Tahun 1967, juncto (jo) Keputusan Bersama Menteri Dalam negeri dan Menteri Penddidikan dan Kebudayaan No.8 tahun 1967 (Djaenuri, 2016).

Sementara itu pada berbagai perguruan tinggi/ universitas negeri maupun swasta mulai mengembangkansebuah program kurikulium yang mengarah pada studi Ilmu Pemerintahan baik sebagai sebuah jurusan dari suatu fakultas ataupun sebagai sebuah bagian dari suatu Fakultas. 


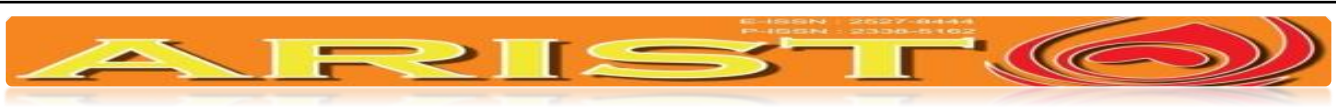

Sosial Politik Humaniora

http://journal.umpo.ac.id/index.php/aristo / aristo@umpo.ac.id

Sebagai contoh adalah Fakultas Tata praja Makassar (yang kemudian menjadi salah satu unsur penting dari Universitas Hasanuddin Makassar, dimana pada tahun 1957 Mr.Tjia Kok Tjiang telahberusaha mengembangkan Ilmu Pemerintahan dengan kuliah umum yang berjudul: "Arti dan Bidang Ilmu Pemerintahan”.Dengan didirikannya jurusan Ilmu Pemerintahan sejak tahun 1990an diberbagai universitas negeri di provinsi-provinsi, maka Ilmu Pemerintahan telah menjadi salah satu program studi dalam Fakultas Ilmu Sosial dan Ilmu Politik (FISIP) yang kita kenal hari ini. Diantaranya universitas-universitas tersebut adalah Universitas Hasanuddin Makassar (dulu Ujung Pandang), Padjadjaran di Bandung, Diponogoro di Semarang, Sam Ratulangi di Manado, Universitas Riau di Pekanbaru, Lambung Mangkurat di Banjarmasin, Mulawarman di Samarinda dan lain-lain. (Alfian dan Mukmin (ed), 1985).

Perkembangan terakhir perjalanan Ilmu Pemerintahan sebagai ilmu yang mandiri, ditempuh melalui jalur akademik maupun jalur profesional. Jalur akademik dimaksudkan untuk menghasilkan tenaga ilmuwan pada jenjang S1, S2, atau S3 dari berbagai Universitas dan Sekolah Tinggi. Sedangkan jalur profesional dipersiapkan untuk melahirkan tenaga-tenaga yang terampil sebagai kader-kader pemerintahan yang berasal institusi kedinasan/ akademi yang berasal dari Institut Ilmu Pemerintahan (IIP) yang sejak tahun 2004 dilebur dengan Sekolah Tinggi Pemerintahan Dalam Negeri (STPDN)sehingga sekarang bernama Institut Pemerintahan Dalam Negeri (IPDN) dan berada dibawah naungan Kementrian Dalam Negeri Republik Indonesia. Dengan demikian, fungsi akademik Ilmu Pemerintahansecara pelan tapi pasti akan mampu mengejar ketertinggalannya dari pesatnya pengembangan keilmuan ilmu-ilmu sosial lainnya.

Berdasarkan rangkaian kesejarahan, Ilmu Pemerintahan sebagai suatu ilmu pengetahuan mulai diajarkan setelah Indonesia merdeka. Perguruan-perguruan tinggi yang membuka jurusan Ilmu Pemerintahan pada awal mulanya antara lain Universitas Gajah Mada, baru kemudian disusul oleh universitasbesar lainnya seperti Universitas Padjadjaran, Universitas Diponegoro, Universitas Hassanudin dan lain-lain, kemudianberkembang pesat diseluruh Indonesia beragam hingga hari ini. 


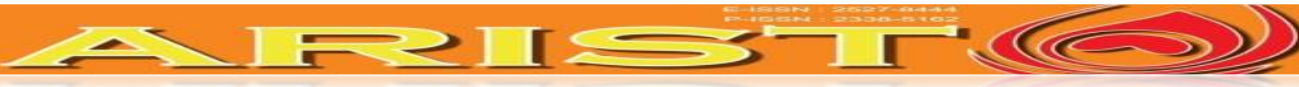

Sosial Politik Humaniora

http://journal.umpo.ac.id/index.php/aristo / aristo@umpo.ac.id

Tabel 1 Perjalanan SejarahIlmu Pemerintahan di Indonesia

\begin{tabular}{|c|c|c|c|}
\hline NO & PERIODE & INSTITUSI/ LEMBAGA & TAHUN \\
\hline 1 & $\begin{array}{l}\text { Pra- } \\
\text { Kemerdekaan }\end{array}$ & $\begin{aligned} \text { - OSVIA (Opleiding School Voor Inlands } \\
\text { Ambtenaren) } \\
\text { - MOSVIA (Middelbaar School van Inheemse } \\
\text { Ambtenaren) }\end{aligned}$ & 1920 \\
\hline \multirow{5}{*}{2} & \multirow{5}{*}{$\begin{array}{l}\text { Awal } \\
\text { Kemerdekaan }\end{array}$} & - Akademi Ilmu Politik (AIP) & 1948 \\
\hline & & $\begin{array}{l}\text { - Fakultas Hukum, Sosial dan Politik (FHSP) + } \\
\text { Ekonomi (FHESP) }\end{array}$ & 1952 \\
\hline & & - Fakultas Sosial \&Politik (FSP) UGM & 1955 \\
\hline & & - Akademi Pemerintahan Dalam Negeri (APDN) & 1956 \\
\hline & & - Institut Ilmu Pemerintahan (IIP) & 1967 \\
\hline \multirow{3}{*}{3} & \multirow{3}{*}{ Masa Kini } & $\begin{array}{l}\text { - Sekolah Tinggi Pemerintahan Dalam Negeri } \\
\text { (STPDN) }\end{array}$ & 1988 \\
\hline & & $\begin{array}{l}\text { - Mulai tumbuh dan berkembang pesat diberbagai } \\
\text { Perguruan Tinggi (Universitas/ Sekolah Tinggi) } \\
\text { di seluruh Indonesia }\end{array}$ & $\begin{array}{l}\text { Sejak } \\
\text { 1990an - } \\
\text { Kini }\end{array}$ \\
\hline & & - Institut Pemerintahan Dalam Negeri (IPDN) & $\begin{array}{l}\text { Sejak } \\
2004- \\
\text { Kini }\end{array}$ \\
\hline
\end{tabular}

Sumber : Berdasarkan data hasil olahan dari berbagai sumber

Berdasarkan urutan kesejarahan sebagaimana yang dirunut diatas, tentunya juga terdapat perubahan dan pergeseran paradigmatik yang terjadi pada Ilmu Pemerintahan di Indonesia. Seiring dengan fase-fase sejarah yang telah dilaluinya,dapat disederhanakan pada tabel berikut ini: 


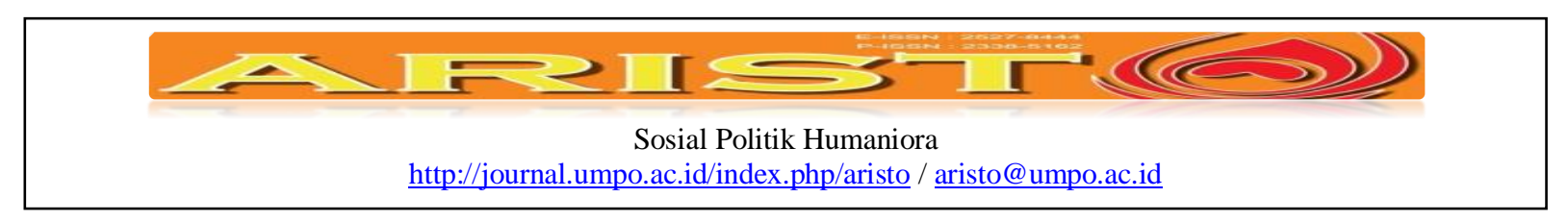

Tabel 2 Perjalanan Paradigmatik Ilmu Pemerintahan di Indonesia

\begin{tabular}{|c|c|c|}
\hline NO & PARADIGMA & CORAK/ NUANSA \\
\hline 1 & $\begin{array}{c}\text { I } \\
\text { 1920-1940an }\end{array}$ & $\begin{array}{l}\text { Ilmu Pemerintahan berwatak normatif, hukum positif, dan diajarkan sebagai } \\
\text { ilmunya pangreh praja kemudian menjadi pamong praja pada zaman Kolonial } \\
\text { Belanda }\end{array}$ \\
\hline 2 & $\begin{array}{c}\text { II } \\
1948-1955\end{array}$ & $\begin{array}{l}\text { Adalah ilmu yang akrab dengan ilmu politik yang terwujud dalam Akademi } \\
\text { Ilmu Politik (AIP) dan setelah itu tergabung dalam Fakultas Hukum, Sosial, } \\
\text { Politik }+ \text { Ekonomi (FHSP } \rightarrow \text { HESP } \rightarrow \text { FSP) Universitas Gajah Mada (UGM) } \\
\text { Jogjakarta. }\end{array}$ \\
\hline 3 & $\begin{array}{c}\text { III } \\
\text { 1956-1980an }\end{array}$ & $\begin{array}{l}\text { Ilmu Pemerintahan yang diajarkan pada Akademmi Pemerintahan Dalam } \\
\text { Negeri (APDN) Malang yang diselenggarakan oleh Kementerian Dalam Negeri } \\
\text { dan dibuka pada tahun } 1956 \text { dan Institut Ilmu Pemerintahan (IIP), lebih dekat } \\
\text { dengan ilmu Administrasi Negara (dikombinasikan dengan pola pemerintahan } \\
\text { Indonesia) daripada ilmu politik. }\end{array}$ \\
\hline 4 & $\begin{array}{c}\text { IV } \\
1988-1993\end{array}$ & $\begin{array}{l}\text { Pada Masa Mendagri Rudini, tetap dengan corak dan nuansa yang sama dengan } \\
\text { paradigma sebelumnya, namun karena pembentukan calon tenaga atau kader } \\
\text { pemerintahan yang dipusatkan di Sekolah Tinggi Pemerintahan Dalam Negeri } \\
\text { (STPDN) Jatinangor melalui sistem Pengajaran, Pelatihan dan Pengasuhan } \\
\text { (Jarlatsuh) } 24 \text { jam model militersitik (doktrin-doktrin militer), sehingga } \\
\text { memiliki cita rasa tersendiri. }\end{array}$ \\
\hline 5 & $\begin{array}{c}\mathrm{V} \\
1993-1996\end{array}$ & $\begin{array}{l}\text { Prinsip-prinsip Manajemen dalam pemerintahan terlihat jelas melalui ruang } \\
\text { lingkup materi pokok kurikulumnya di berbagai universitas yakni asas dan } \\
\text { sistem pemerintahan; hukum tata pemerintahan; ekologi pemerintahan; filsafat } \\
\text { dan etika pemerintahan; praktik penyelenggaraan pemerintahan; kepemimpinan } \\
\text { pemerintahan; reformasi pembangunan daerah. }\end{array}$ \\
\hline 6 & $\begin{array}{l}\text { VI } \\
1996,2000,2013- \\
\text { Sekarang }\end{array}$ & $\begin{array}{l}\text { Ilmu Pemerintahan dikembangkan melalui program kerjasama Universitas } \\
\text { Padjajaran/UNPAD-IIP,yang menyelenggarakan Program Magister Ilmu-ilmu } \\
\text { Sosial dengan Bidang Kajian Utama (BKU) Ilmu Pemerintahan (1996), dan } \\
\text { Program Doktor Ilmu-Ilmu Sosial Konsentrasi Ilmu Pemerintahan (2000). } \\
\text { Kemudian IPDN menyelenggarakan Program Ilmu Pemerintahan hingga pada } \\
\text { derajat akademik tertinggi (S3) atau Doktor Ilmu Pemerintahan (2013). Pada } \\
\text { fase ini, Ilmu Pemerintahan adalah ilmu yang berangkat dari manusia kembali } \\
\text { kepada manusia. }\end{array}$ \\
\hline
\end{tabular}

Sumber : Berdasarkan data hasil olahan dari berbagai sumber 


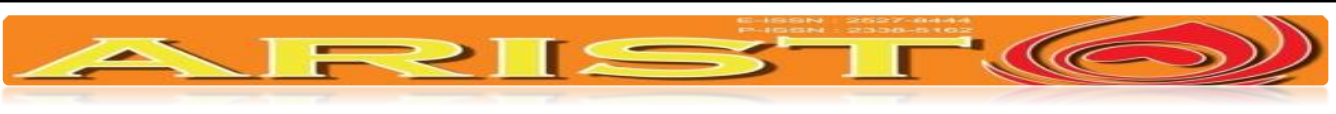

Sosial Politik Humaniora

$\underline{\text { http://journal.umpo.ac.id/index.php/aristo / aristo@umpo.ac.id }}$

\section{Lokus/ Kedudukan Ilmu Pemerintahan Diantara Ilmu-Ilmu Kenegaraan Lainnya}

Ilmu Pemerintahan sejak awal perkembangannya telah dikemukakan oleh Van Poelje pada tahun 1926 dan kemudian menerbitkan sebuah buku yang berjudul Algemene Inleiding tot de Bestuurkunde pada tahun 1942 dan (cetakan pertama) dan cetakan kedua terbit pada tahun 1953. Buku tersebut kemudian diterjemahkan kedalam bahasa Indonesia oleh Drs. B. Mang Reng Say (1978) dengan judul Pengantar Umum Ilmu Pemerintahan dimana Van Poelje mengemukakan bahwa "de bestuurkunde leert, hoe men de openbaare dienst in richt en leidt" yang artinya Ilmu Pemerintahan adalah ilmu yang mengajarkan bagaimana dinas umum (openbaare dienst) disusun dan dipimpin dengan sebaik-baiknya. Sedangkan Hoogerwerf (1983) dalam bukunya Over Heids Beleidyang diterjemahkan kedalam bahasa Indonesia oleh R.L.L Tobing yang berjudul Ilmu Pemerintahan mengemukakan pendapat bahwa ruang lingkup pemerintahan adalah mempelajari bentuk-bentuk pemerintahan dengan berbagai kebijakan yang dibuatnya. Meskipun demikian, perjalanannya eksistensinya tidaklah berjalan mulus. Ada yang memandang Ilmu Pemerintahan itu bukan merupakan suatu ilmu pengetahuan tetapi hanya merupakan studi/kajian terhadap praktek penyelenggaraan pemerintahan. Sebaliknya ada yang memandang Ilmu Pemerintahan sebagai ilmu pengetahuan yang mandiri, yang mempunyai obyek telaah sendiri dan yang dapat dibedakan dengan ilmu pengetahuan yang lainnya, yang dalam perkembangan akhir-akhir ini justru meluas dalam menyoroti obyek telaahnya, yaitu tidak hanya menyoroti hubungan antara pemerintah dan diperintah dalam lingkup Negara, akan tetapi setiap gejala pemerintahan yang menggambarkan adanya hubungan antara yang "memerintah" dengan yang "diperintah"yang berada diluar lingkup Negara pun menjadi obyek studi Ilmu Pemerintahan.

Ada juga yang memandang Ilmu Pemerintahan itu merupakan cabang dari Ilmu Politik atau bagian dari Ilmu Politik. Hal ini dapat dipahami juga mengingat obyek studi Ilmu Pemerintahan itu telah lama menjadi bagian dari obyek studi Ilmu Politik, hal ini Nampak jelas apabila dipahami dari sisi lingkup batasan dari konsep politik itu sendiri. Sejarah dalam ilmu pengetahuan menunjukkan bahwa Ilmu Pemerintahan merupakan perkembangan lebih lanjut dari Ilmu Politik dan merupakan bagian dari ilmu sosial/ kemasyarakatan, yang merupakan pengembangan lebih lanjut dari filsafat, khususnya filsafat politik (Mustansyir dkk, 2002). Di sisi yang lain, sarjana Administrasi Publik memandang Ilmu Pemerintahan itu sebenarnya adalah ilmu Administrasi Publik. Dalam perkembangannya muncul berbagai pendapat yang berbeda 


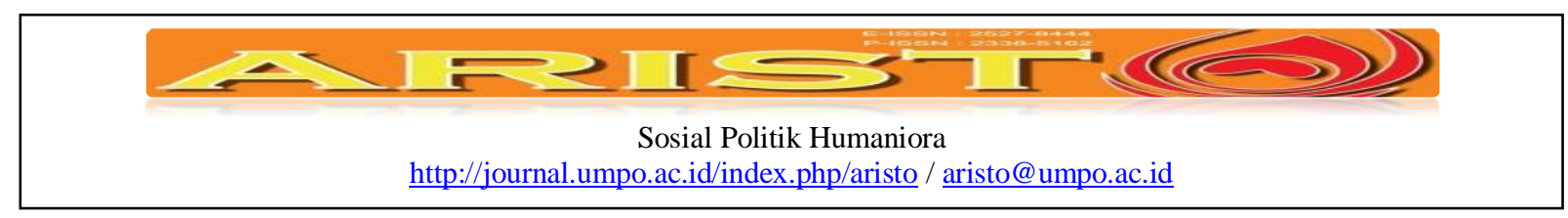

satu sama lain sebagai berikut: (1) Ilmu pemerintahan sama dengan Ilmu Administrasi Negara; (2) Ilmu Politik itu sebenarnya adalah Ilmu Pemerintahan; (3) Ilmu Pemerintahan berbeda dengan Ilmu Administrasi Negara, masing-masing berdiri sendiri; (4) Pemerintahan sekedar seni saja; (5) Ilmu Pemerintahan bagian dari Ilmu Politik; (5) Ilmu Administrasi Negara bagian dari Ilmu Pemerintahan (Yossi Adiwisastra dalam Labolo dkk,2008).

Namun demikian, ada sebagian teoritisi, praktisi, dan pemerhati pemerintahan yang tertarik terhadap kedudukan Ilmu Pemerintahan, dan pada akhirnya tiba pada satu kesimpulan bahwa Ilmu Pemerintahan merupakan satu ilmu pengetahuan yang otonom. Ilmu pengetahuan adalah satu nama jenis untuk sejumlah bagian yang berdiri sendiri tentang apa yang dikenal oleh manusia. Setiap ilmu pengetahuan meliputi satu bidang yang luas yang dikaitkan satu sama lain dalam hubungan sistematis tertentu. Oleh karena itu, ilmu pengetahuan dapat dipelajari dan dilukiskan serta disampaikan kepada orang lain. Dari rumusan tersebut, jelas bahwa Ilmu Pemerintahan mampu memenuhi syarat-syarat ilmu pengetahuan, sehingga Ilmu Pemerintahan dapat disebut ilmu pengetahuan. Ilmu Pemerintahan terdiri atas sekelompok pengetahuan yang sejenis berkaitan satu sama lain dan tersusun secara rapi, teratur dan sistematis (Bayu Suryaningrat dalam Labolo dkk, 2008).

Ilmu Pemerintahan dapat dikatakan sebagai suatu ilmu pengetahuan jika jelas dan tegas landasan ontologi, epistimologi dan aksiologinya. Ontologi bertanya tentang apa yang ingin diketahui, diamati, diteliti, dipelajari dan dibahas oleh ilmu atau apa yang menjadi bidang telaah dari Ilmu Pemerintahan. Walaupun belum begitu tegas tetapi perbedaanya dapat dipahami jika dibandingkan dengan obyek telaah dari ilmu-ilmu pengetahuan kenegaraan lainnya. Landasan ontologi ilmu merupakan jawaban atas pertanyaan utama yaitu apa yang ingin diketahui ilmu atau apa telaah ilmu. Ilmu berbeda dengan pengetahuan. Ilmu mengkaji masalah-masalah yang telah diketahui atau yang ingin diketahui yang tidak terselesaikan dalam pengetahuan sehari-hari. Masalah-masalah tersebut terbatas pada obyek yang berada dalam jangkauan pengalaman manusia dan dapat diuji oleh pengalaman manusia (Jujun Suriasumantri dalam Mustanyir dkk, 2002). Jika dikaji dari aspek epistimologi, dimana epistimologi pada hakekatnya membahas secara mendalam berkenaan dengan metode-metode dan pendekatan-pendekatan yang digunakan untuk memperoleh kebenaran ilmiah, maka Ilmu Pemerintahan dalam proses mencari kebenaran ilmiah juga menggunakan metode-metode dan pendekatan-pendekatan yang digunakan oleh ilmu 


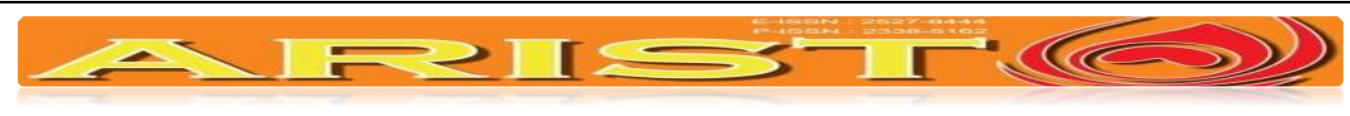

Sosial Politik Humaniora

http://journal.umpo.ac.id/index.php/aristo / aristo@umpo.ac.id

sosial lainnya. Metode-metode yang dibangun berdasarkan pada metode penelitian sosial dan metode penelitian dalam wilayah pemerintahan, yang pada akhirnya diperoleh metodologi Ilmu Pemerintahan. Dari sisi metodologi inilah kekhasan Ilmu Pemerintahan dapat dilihat dan dikembangkan baik dalam kerangka pengembangan Ilmu Pemerintahan itu sendiri sebagai ilmu pengetahuan dan juga digunakan untuk memecahkan masalah-masalah pemerintahan yang terjadi dalam waktu tertentu dan lingkungan tertentu. Pada akhirnya, pertanyaan berikutnya yang perlu diajukan untuk menyoroti Ilmu Pemerintahan dari perspektif filsafat ilmu adalah aspek aksiologis atau apa manfaat Ilmu Pemerintahan terhadap kehidupan manusia pada umumnya dan pemecahan masalah-masalah pemerintahan pada khususnya. Landasan aksiologi ilmu berkaitan dengan masalah arah yang dituju oleh ilmu tersebut. Ilmu dikembangkan manusia pada mulanya sebagai teoria yaitu bertujuan untuk mendalami pengertian diri manusia dan alam sekitarnya, sehingga manusia dapat sampai pada inti dirinya. Ilmu dimaksudkan agar manusia mampu menjadi manusia yang sungguh-sungguh menyadari diri dan kedudukannya yang unik dalam jagat raya ini. Kemudian tujuan ilmu mengarah kearah praktis menyangkut masalah keperluan manusia untuk mempertahankan hidupnya dan keinginan untuk meningkatkan kemungkinankemungkinan yang terjadi dalam kehidupan (Melsen dalam Mustansyir dkk, 2002).

Untuk memperluas pemahamantentang Ilmu Pemerintahan sebagai ilmu pengetahuan yang mandiri dengan obyek telaahannya, Yosef Riwu Kaho berpendapat bahwa Ilmu Pemerintahan merupakan suatu ilmu pengetahuan yang teratur (pendapat ini didasarkan pada kesimpulan bahwa yang disebut dengan ilmu adalah sesuatu yang memiliki ciri-ciri sebagai pengetahuan yang teratur; mempunyai obyek sasaran tertentu yang dibahasnya; adanya pusat perhatian tertentu sebagai sudut pandangan dalam membahas obyeknya; menggunakan metode-metode ilmiah tertentu dalam usahanya untuk mencapai kebenaran yang obyektif). Ilmu Pemerintahan juga memiliki obyek/sasaran yang dibahas atau dipelajarinya, yaitu pemerintahan. Pemerintahan disini dipandang sebagai segala usaha atau kegiatan yang terorganisir, bersumber pada kedaulatan, dan berlandaskan pada dasar negara mengenai rakyat/penduduk, serta wilayah Negara demi tercapainya tujuan Negara atau secara ringkas dapat dikatakan bahwa pemerintahan adalah suatu sistem dari berbagai fungsi yang dilaksanakan atas dasar-dasar tertentu untuk mewujudkan tujuan Negara. Suatu tugas atau fungsi hanya dapat dilaksanakan jika disertai kewenangan dan kekuasaan. Oleh karena itu, seringkali pemerintahan juga dapat dikatakan 


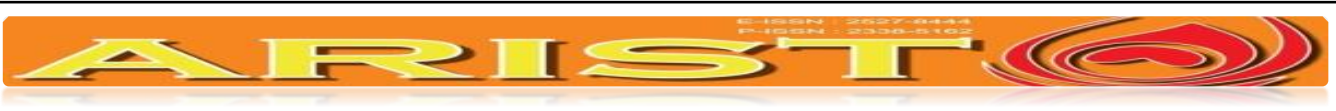

Sosial Politik Humaniora

http://journal.umpo.ac.id/index.php/aristo / aristo@umpo.ac.id

sebagai kekuasaan Negara. Kekuasaan Negara menurut A.M Donner terbagi menjadi dua jenis :taak en doelstelling (penentuan tugas dan tujuan) dan uitvoering (eksekusi atau pelaksanaan terhadap tugas dan tujuan yang telah ditetapkan) (Yosef Riwu Kaho dalam Labolo dkk, 2008). Hal senada juga dikemukakan oleh Herman Finner, bahwa pemerintahan itu meliputi : (1) The process of politics, and (2) The process of administration. Dari pendapat ini dapat disimpulkan bahwa obyek studi Ilmu Pemerintahan itu meliputi proses perumusan kebijakan pemerintah (dalam area politis) dan proses pelaksanaan kebijakan (dalam area administrative/teknis), sehingga Herman Finner dalam bukunya Theory and Practice of Modern Governmentmengatakan dengan sebuah jargon yang ramah ditelinga kita yaitu "government is politics plus administration (Finner, 1949).

Pendapat yang sedikit berbeda dikemukakan oleh Mustansyir, dkk (2002) yang antara lain dijelaskan bahwa penelaahan ilmiah tentang pemerintahan dalam proses spesialisasi menjadi sub-spesialisasi Ilmu Politik atau dengan kata lain tinjauan Ilmu Pemerintahan tidak dapat lepas dari Ilmu Politik maupun ilmu masyarakat. Sementara itu pada proses kesadaran akan penyatuan ilmu, penelaahan ilmiah tentang pemerintahan masuk dalam studi atau ranah ilmu yang didalamnya mencakup aspek politik maupun sosial disamping aspek-aspek yang lain. Di dalam studi pemerintahan, pemerintahan sebagai obyek material tidak hanya ditinjau dari aspek politik yang merupakan akar dari Ilmu Pemerintahan (dalam proses spesialisasi) tetapi ditinjau juga dari aspek-aspek yang lain yang berkaitan dengan spesialisasi ilmu-ilmu yang lain. Tinjauan dari segi politik maupun aspek yang lain (misalnya sosial, hukum, filosofi) bukan sebagai tinjauan yang mengatasi persoalan pemerintahan tetapi semua tinjauan tersebut berada dibawah payung paradigmaIlmu Pemerintahan. Berdasarkan pendapat ini dapat dikemukakan bahwa Ilmu Pemerintahan itu dalam perkembangannya menjadi ilmu yang mandiri banyak dipengaruhi oleh Ilmu Politik dan ilmu sosial lainnya, dan atas dasar itu obyek studi maupun metodenya tidak dapat dilepaskan dari hubungannya dengan ilmu-ilmu tersebut.

Sebagai pembanding dapat juga dikemukakan pendapat Sadu Wasistiono, bahwa obyek studi Ilmu Pemerintahan adalah hubungan antara Negara dengan rakyatnya dalam konteks kewenangan dan pelayanan publik. Lebih jauh ia berpendapat bahwa obyek Ilmu Pemerintahan dapat dibagi menjadi dua: (1) Obyek materia Ilmu Pemerintahan adalah Negara; (2) Obyek forma Ilmu Pemerintahan adalah hubungan antara Negara dengan rakyatnya dalam konteks 


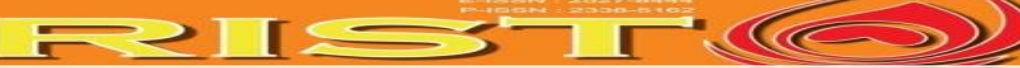

Sosial Politik Humaniora

http://journal.umpo.ac.id/index.php/aristo / aristo@umpo.ac.id

kewenangan dan pelayanan publik (Wasistiono dan Simangunsong, 2009). Sedangkan Ndraha dalam bukunya berpendapat bahwa obyek materia Kybernologi (Ilmu Pemerintahan Paradigma Baru) adalah ilmu pengetahuan yang bertujuan memimpin hidup bersama manusia kearah kebahagiaan yang sebesar-besarnya, tanpa merugikan orang lain secara tidak sah. Sedangkan obyek formanya didefinisikan sebagai bangunan pengetahuan (Body of Knowledge) yang merupakan hasil rekontruksi pemahaman terhadap pendaratan bestuurkunde, bestuurwetenschap, dan bestuurwetenschappen di bumi Indonesia pada sudut pandang kemanusiaan, guna mengimbangi sudut pandang kekuasaan, dan pengaitannya dengan sudut pandang lain yang berbeda (Ndraha, 2003).

Selain itu, Syafiie (2011) juga menjelaskan posisi dan kedudukan Ilmu Pemerintahan diantara ilmu-ilmu kenegaraan lainnya yang berkutat pada pusaran yang dekat dan hampir sama, namun tetap saja focus of interest nya dapat dibedakan, sebagaimana yang dapat dilihat pada tabel berikut ini:

Tabel 3 Objek Materia dan Objek Forma Ilmu-Ilmu Kenegaraan

\begin{tabular}{|c|c|c|c|}
\hline NO & $\begin{array}{l}\text { NAMA DISPLIN ILMU } \\
\text { PENGETAHUAN }\end{array}$ & $\begin{array}{l}\text { OBJEK } \\
\text { MATERIA }\end{array}$ & OBJEK FORMA \\
\hline 1 & Ilmu Negara & Negara & $\begin{array}{l}\text { Konstitusi, pertubuh- kembangan negara, } \\
\text { lahir dan tenggelammnya negara. }\end{array}$ \\
\hline 2 & Ilmu Pemerintahan & Negara & $\begin{array}{l}\text { Hubungan pemerintahan, gejala- gejala } \\
\text { pemerintahan, peristiwapemerintahan. }\end{array}$ \\
\hline 3 & Ilmu Politik & Negara & $\begin{array}{l}\text { Kekuasaan, partai politik, kelompok } \\
\text { penekan, kepentingan masyarakat. }\end{array}$ \\
\hline 4 & $\begin{array}{l}\text { Ilmu Ilmu Hukum Tata } \\
\text { Negara }\end{array}$ & Negara & $\begin{array}{l}\text { Hukum, peraturan perundang- undangan, } \\
\text { konstitusi dan konvesi. }\end{array}$ \\
\hline 5 & Ilmu Administrasi Negara & Negara & $\begin{array}{l}\text { Pelayanan, organisasi pemeintahan dan } \\
\text { manajemen pemerintahan }\end{array}$ \\
\hline
\end{tabular}

Sumber : Syafiie (2011)

Bertolak dari beberapa pengertian dan pendapat diatas, dapat dikemukakan bahwa obyek materia dari Ilmu Pemerintahan adalah Negara (pemerintah sebagai salah satu unsur dari Negara), sedangkan obyek formanya adalah kegiatan-kegiatan pemerintahan dan hubunganhubungan pemerintahan (ada yang bersifat politis dan ada yang bersifat teknis). Berdasarkan pemahaman tersebut tampak bahwa Ilmu Pemerintahan termasuk dalam rumpun ilmu-ilmu pengetahuan yang menjadikan Negara sebagai obyek materianya bersama-sama dengan ilmu- 


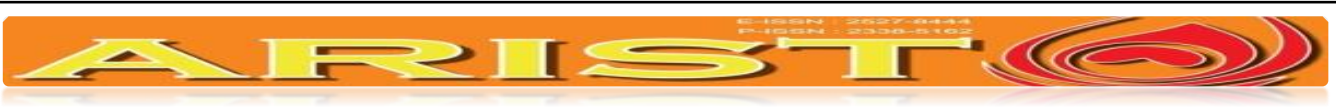

Sosial Politik Humaniora

http://journal.umpo.ac.id/index.php/aristo / aristo@umpo.ac.id

ilmu kenegaraan lainnya seperti Ilmu Politik, Ilmu Administrasi Negara/Publik, Ilmu hukum, dan Ilmu Negara itu sendiri.Dengan demikian, Ilmu Pemerintahan tetap bisa dibedakan dengan ilmuilmu kenegaraan lainnya terutama dengan Ilmu Politik. Ilmu Politik terfokus pada kajian fenomena kekuasaan, sedangkan Ilmu Pemerintahan memusatkan perhatian pada fenomena kekuasaan dalam berbagai ranah publik (kewenangan/ kekuasaan legal). Pengkajian kekuasaan dalam ranah publik inilahyang membedakan kajian Ilmu Pemerintahan dengan kajian Ilmu Politik yang pada umumnya mendalami fenomena kekuasaaan dalam ranah private kekuasaan murni. Dari pemahaman posisional itu, maka objek forma atau sasaran utama dari Ilmu Pemerintahanadalahpemerintahan Indonesia dan segala sesuatu yang berkaitan dengannya.

Namun, proses menuju kematangan, masih terdapat beberapa masalah terkait nomenklatur atau penamaan Program Studi Ilmu Pemerintahan di Indonesia.Akan tetapi, Ilmu Pemerintahan di Indonesia yang telah ditubuhkan dalam sebuah wadah berskala nasional dengan nama Kesatuan Program Studi Ilmu Pemerintahan Indonesia (KAPSIPI), kemudian berupaya memberikan masukan kepada Pemerintah tentang nomenklatur atau penamaan Program Studi Ilmu Pemerintahan, dimana dalam draft awal yang dirancang oleh Kemenristek Dikti menyebutkan bahwa Program Studi Ilmu Pemerintahan sebagai studi Kepemerintahan dengan gelar kesarjanaan Sarjana Sosial (S.Sos). Keadaan ini menjadi agenda penting yang dibahas dalam Simposium Ilmu Pemerintahan yang digagas oleh Universitas Padjadjaran Bandung pada 23-24 November 2014. Berdasarkan usulan dan tuntutan dari Ketua Program Studi Ilmu Pemerintahan se-Indonesia, sebagai tindak lanjutnya, pengurus KAPSIPI menyampaikan surat Kepada Kemenristek Dikti untuk menyampaikan masukan nama program studi dan gelar kesarjanaanya yaitu :

1. Nama Program Studi : Ilmu Pemerintahan (Government Science)

2. Gelar Kesarjanaan;
a. Strata satu (S1) : Sarjana Ilmu Pemerintahan (S.I.P.)
b. Strata dua (S2) : Magister Ilmu Pemerintahan (M.I.P)
c. Strata tiga (S3) : Doktor Ilmu Pemerintahan (Dr)

Dari usulan tersebut, Mentri kemudian menerbitkan Peraturan Menteri Riset, Teknologi, dan Pendidikan Tinggi Republik Indonesia Nomor 15 Tahun 2017Tentang Penamaan Program Studi Pada Perguruan Tinggiyang sudah mengakomodir dan mengakui keberadaan Ilmu 


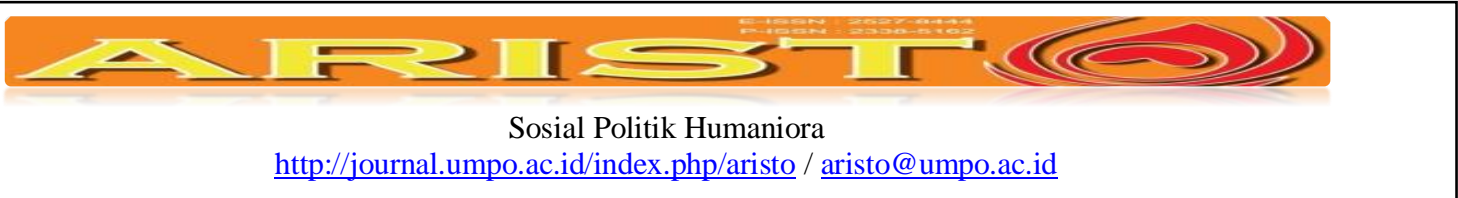

Pemerintahandi Indonesia bersamaan dengan ilmu-ilmu lainnya. Peraturan atau Kepmenristek Dikti Nomor 257/M/KPT/2017 yang dimaksud dapat dilihat pada tabel di bawah ini :

Tabel 4 Nomenklatur / Penamaan Program Studi Ilmu-ilmu Kenegaraan Pada Perguruan Tinggi di Indonesia

\begin{tabular}{|c|c|c|c|c|c|c|}
\hline \multirow[b]{2}{*}{ No } & \multirow{2}{*}{$\begin{array}{c}\text { NAMA PROGRAM } \\
\text { STUDI DALAM } \\
\text { BAHASA } \\
\text { INDONESIA }\end{array}$} & \multirow{2}{*}{$\begin{array}{c}\text { NAMA PROGRAM } \\
\text { STUDI DALAM } \\
\text { BAHASA } \\
\text { INGGRIS }\end{array}$} & \multicolumn{3}{|c|}{ PROGRAM } & \multirow[b]{2}{*}{ Gelar } \\
\hline & & & $\mathbf{S}$ & $\mathbf{M}$ & Dr & \\
\hline 1 & Ilmu Hukum & Law & $\sqrt{ }$ & $\sqrt{ }$ & $\sqrt{ }$ & $\mathrm{H}$. \\
\hline 2 & $\begin{array}{lll}\text { Ilmu atau Sains } \\
\text { Politik }\end{array}$ & Poliical Science & $\sqrt{ }$ & $\sqrt{ }$ & $\sqrt{ }$ & Sos. \\
\hline 3 & $\begin{array}{l}\text { Ilmu Administrasi } \\
\text { Negara/ Publik }\end{array}$ & $\begin{array}{l}\text { Public } \\
\text { Administrastion }\end{array}$ & $\sqrt{ }$ & $\sqrt{ }$ & $\sqrt{ }$ & A.P. \\
\hline 4 & $\begin{array}{l}\text { Studi } \\
\text { Pemerintahan }\end{array}$ & Government Studies & $\sqrt{ }$ & $\sqrt{ }$ & $\sqrt{ }$ & I.P. \\
\hline
\end{tabular}

Sumber : diolah dari Salinan Peraturan Mentri Ristekdikti No. 5 Tahun 2017

Walaupun Peraturan Mentri tersebut sebagian besar telah mengakomodir usulan dan masukan KAPSIPI, namun sebagai catatan penting yang juga harus diperhatikan, bahwa peraturan tersebut masih terlihat bias dan mengandung sedikit kerancuan atau ketidakseragaman antara nama Program Studi dengan Gelar yang diterima. Sebagai contoh, Ilmu Politik yang bahkan telah diakui sebagai Ilmu atau sains didunia internasional (Political Sains) justru mengalami langkah mundur dan mendapat gelar Sarjana Sosial (S.Sos.) yang sebelumnya bergelar Sarjana Ilmu Politik (S.IP). Pada Program Studi Ilmu Pemerintahan, "Ilmu Pemerintahan" dimulai dengan kata "Studi" terlebih dahulu, kemudian disusul dengan kata "Ilmu" yang berada dalam tanda kurung.Hal ini tentunya membuat para pegiat Ilmu Pemerintahan menjadi bertanya-tanya, apakah kata "studi" itu disamakan dengan kata "ilmu"? kalau hal itu terjadi hanya karena kesalahanredaksional saja masih dapat dimaklumi. Akan tetapi apabila ditetapkan atau dikatakan lagi bahwa kata "studi" itu sama/ sederajad atau disamakan/ disederajadkan dengan kata "ilmu" maka hal ini juga merupakan langkah mundur dan akan berimplikasi negatif bahkan dapat mengancam eksistensi dan harga diri Ilmu Pemerintahan dikemudian hari.Sebagaimana telah disebutkan sebelumnya, bahwa ada perbedaan definisi 


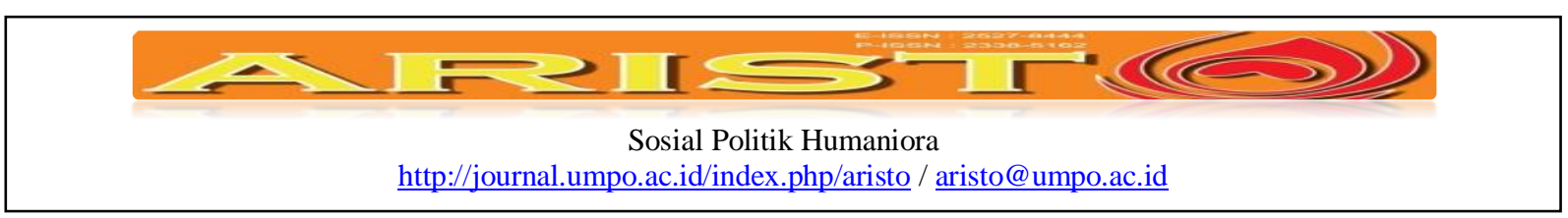

tentang ilmu dan pengetahun (kajian/studi), didukung dengan teori-teori yang berasal dari berbagaipandangan dan pendapat para ahli. Bila itu yang terjadi, tentunya hal tersebut sangat disayangkan dan harus ada upaya hukum lanjutan agar Ilmu Pemerintahan secara tegasmenjadi "baku"atau diakui dan diatursecara legal/formal oleh pemerintah dan bukan hanya sekedar disebut, dipakai, dan dikenal sebagai "ilmu" dalam pengertian ilmu pengetahuan yang telah berdiri sendiridan memiliki Body of Knowledge (BOK), dan telah "duduk"secara mapan baik dari segi ontologis, epistemologis, aksiologis oleh para ilmuwannya.

Berdasarkan uraian dan pemaparan, serta argumentasi dari banyak pakar dan ahli, disertai dengan berbagai teori dan bukti-bukti hingga hari ini, nampaknya selain upaya secara formal, upaya secara moral juga harus dilakukan dengan cara lebih menggiatkan aktifitas penelitian dan publikasi ilmiahdalam arena Ilmu Pemerintahan, hingga semakin mampu menimbulkan dampak "pembeda"yang tegas dan jelasdengan bidangatau ilmu-ilmu kenegaraanlainnya dalam rangka menjaga eksistensi dan harga diri sebuah ilmu pengetahuan.

\section{Kesimpulan}

Dari rangkaian penelitian melaluipenyelidikan (inquisitorial) terhadap sumber dan bahanbahan kepustakaan, dapat disimpulkan bahwa pada dasarnya Ilmu Pemerintahan telah mengarungi lintasan perjalanan sejarah yang sangat panjangdan penuh tantangan yang dimulai sejak zaman pra-kemerdekaan (kolonial Belanda) dan telah melalui proses dalam siklus hidup sebuah ilmu pengetahuan yang sesuai dengan pembabakan dan tahapan dalam prinsip-prinsip serta hukum-hukum penemuan ilmiah. Kendatipun lokus (kedudukan) Ilmu Pemerintahan telah diungkapdan dijelaskan melalui berbagai teori, pendapat, dan pandangan para ahli, namunmasih terlihat adanya symptom atau gejala yang harus diwaspadai oleh segenappegiat dan pelakuIlmu Pemerintahan, mengingat bidang cakupannya yang memang sangat luas, membuat semua pihak yang bertanggung jawab pada ilmu ini harus berupaya untuk merapatkan barisan dan menyamakan pendapat pada hal-hal yang masih belum disepakati sehingga Ilmu Pemerintahan mampu menghadapi berbagai tantangan yang lebih besar dan dinamis dimasa yang akan datang.

Berdasarkan situasi dan kondisi yang ada, maka penguatan ontologi, epistemologi, dan aksiologiIlmu Pemerintahan harus terus mendapatkan porsi yang cukupagar jati diri Ilmu Pemerintahan yang sesungguhnya tetap berdiri kokoh, sembari melakukan kajiandengan cakupan 


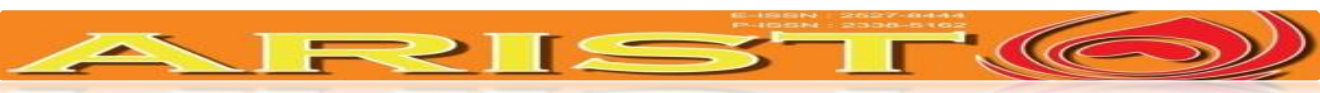

Sosial Politik Humaniora

http://journal.umpo.ac.id/index.php/aristo / aristo@umpo.ac.id

wilayah interdisipliner, multidisipliner, bahkan transdisipliner, mengingat ciri dari sebuah ilmu pengetahuan bersifat dinamis, yang bermakna harus ada sebuah upaya dan ikhtiar yang berkesinambungan dari para pelopor/ pakar, pendukung, dan pengguna dari ilmu pengetahuan yang dimaksud agar eksistensi dan harga diri ilmu tersebut tetap terjaga sehingga kebermanfaatannya terhadap peradaban umat manusia kian dirasakan. 


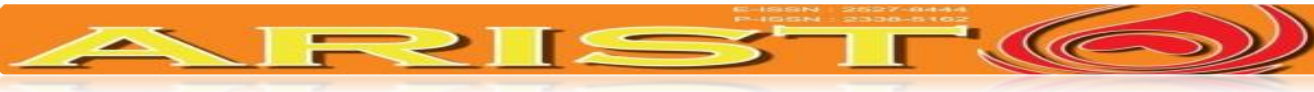

Sosial Politik Humaniora

http://journal.umpo.ac.id/index.php/aristo / aristo@umpo.ac.id

\section{Daftar Pustaka}

Alfian dan Hidayat Mukmin (ed). (1985). Perkembangan Ilmu Politik di Indonesia serta Peranannya Dalam Pemantapan Persatuan dan Kesatuan Bangsa.Jakarta: Rajawali Press. Black’s Law Dictionary, Fith Edition, (1979). Henry Campbell Black. St. Paul Minn-Minnesota, USA: St. Pail Minn West Publishing Co.

Djaenuri, Aries. (2016). Dasar-dasar Ilmu Pemerintahan. Diktat Matakuliah Dasar-Dasar Pemerintahan. Jakarta.

Endarmoko, Eko. (2006). Tesaurus Bahasa Indonesia. Jakarta: Gramedia Pustaka Utama.

Finer, Herman (1949). Theory and Practice of Modern Government. New York:Henry Holt and Company.

Finer, Samuel Edward. (1974). Comparative Government.Harmonds Worth-Middlesex, England: Penguin Books, Ltd.

Gie, The Liang. (1991). Pengantar Filsafat Ilmu. Jogjakarta: Liberty.

Harre, R. (1995). The Philosophies of Science, an Introductory Survey. London, UK: The Oxford University Press.

Hoogerwerf, A (red.). (1983). Ilmu Pemerintahan. R.L.L. Tobing, pent.Jakarta: Erlangga.

Karniawati, Nia. (2015). Hakekat Ilmu Pemerintahan. Jurnal Ilmu Pemerintahan (Cosmogov), Vol.1, No.2, Oktober 2015, 205-215.

Labolo, Muhadam dkk (ed). (2008). Beberapa Pandangan Dasar tentang Ilmu Pemerintahan. Malang: Bayumedia Publishing.

Mustansyir, Rizal dkk (Laporan Penelitian). (2002). Kedudukan Ilmu Pemerintahan Diantara Disiplin Ilmu Lain :Pendekatan Filasafat Ilmu, Program Penelitian Kerjasama Fakultas Filsafat Universitas Gajah Mada dan Institut Ilmu Pemerintahan Departemen Dalam Negeri. IIP: Jakarta.

Ndraha, Taliziduhu. (2003). Kybernologi-Ilmu Pemerintahan Baru. Jakarta: Rineka Cipta.

Pamudji, S.(1983). Kepemimpinan Pemerintahan di Indonesia. Jakarta: Bina Aksara.

Pratikno, (2003). Melacak Ruang Lingkup Kajian PPemerintahan Dalam ilmu Politik. Jurnal Ilmu Sosial dan Ilmu Politik, Vol.1, No.1, September 2003, 15-22. 


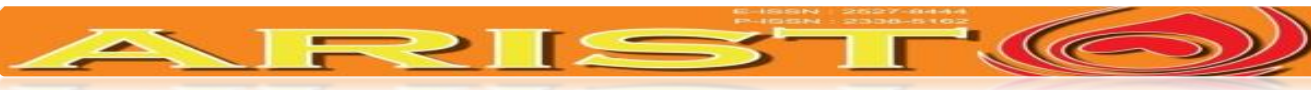

Sosial Politik Humaniora

http://journal.umpo.ac.id/index.php/aristo / aristo@umpo.ac.id

Lay, Cornelis dan Wawan Masudi. (2005). Perkembangan Kajian Pemerintahan. Jurnal Ilmu

Sosial dan Ilmu Politik, Vol.9, No.2, November 2005, 225-240.

Poelje, G.A. Van. (1953). Pengantar Umum Ilmu Pemerintahan. B. Mang Reng Say, pent. Jakarta: Yayasan Karya Dharma, IIP.

Soerjosoedarmo, R. Soemendar. (1985). Perkembangan Konsep Ilmu Pemerintahan- Makalah Disampaikan pada Seminar IPP, Jakarta.

Strong, C.F. (1975). Modern Political Constitution an Introduction to The Comparative Study of Their History and Existing Form. London: Sidwick \& Jackson Ltd.

Surianingrat, Bayu. (1980). Mengenal Ilmu Pemerintahan.Rineka Cipta: Jakarta.

Syafiie, Inu Kencana. (2000). Pengantar Ilmu Pemerintahan. Bandung: Refika Aditama. , Inu Kencana. (2011). Pengantar ilmu politik - Dari Keseimbangan Good Governance Dengan Clean Government Sampai Pada State Of The Art Ilmu Politik Dalam Mengubah Politik Biadab Menjadi Politik Beradab. Bandung: Pustaka Reka Cipta.

Tafsir, Ahmad. (2004). Filsafat Ilmu: Mengurai Ontologi, Epistemologi, dan Aksiologi Pengetahuan. Bandung: Remaja Rosada Karya.

Wasistiono, Sadu. (2003). Ilmu Pemerintahan Masa Kini - Makalah pada Seminar Nasional Ketiga Ilmu Pemerintahan, Intitut Ilmu Pemerintahan, 22 Mei 2003, Jakarta.

, Sadu dan Fernandes Simangunsong. (2009). Metodologi Ilmu Pemerintahan. Jakarta: Penerbit Universitas Terbuka.

Ylst, Fransiscus Van. (2015). Eksistensi Ilmu Pemerintahan. Jurnal Ilmu Pemerintahan (Cosmogov), Vol.1, No.1, April 2015, 1-11. 